\title{
Education Section
}

\section{Complementary Medicine Research Unit}

\author{
George Lewith
}

Community Clinical Sciences, University of Southampton, Southampton, UK

\section{Why is Our Research Unit Important?}

One in ten of the UK population use complementary medicine each year and $\sim 50 \%$ are lifetime users. The recent House of Lords' Report has clearly defined a public need for further research into both safety and efficacy. The Department of Health research capacity building initiative is one of the first main responses to the Select Committee's recommendations. We know that within this emerging field we have developed a unit with cooperative ventures within the university, both intra-faculty and inter-faculty. As a consequence, we have been able to draw in major funding along with a growing body of academic publications.

Our unit was established by George Lewith in 1995 with his appointment as Honorary Visiting Senior Lecturer. He now has a University contract as a Reader within the Department of Primary Care where the unit is located. The unit was initially provided with core funding by the Maurice Laing Foundation and has been able to generate substantial amounts of soft money funding for a number of minor and major projects from charitable (including Wellcome) sources as well as National Health Service Research and Development (NHS R\&D) funding. Laing funding continues to provide our unit with an administrative core. Dr Lewith has been appointed as a Visiting Professor to the School of Integrated Health at the University of Westminster.

The Department of Health is now providing funds for research capacity building within complementary medicine and we have been successful in obtaining Department of Health support for two post-doctoral fellows (Peter White and Sarah Brien) and two PhD students during the first 2 years of the awards. The Department of Health is also funding complementary and alternative medicine (CAM) projects within palliative cancer care (£300 000) and we have successfully applied for this funding, in conjunction with Jessica Corner as the primary investigator. Wellcome is currently funding $37 \%$ of the applications it puts out for review in the field of

\footnotetext{
For reprints and all correspondence: George Lewith, Honorary Senior Research Fellow, Department of Medicine, Southampton General Hospital, Southampton, UK. Tel: +44-0-23-8024-1073; E-mail: GL3@ soton.ac.uk
}

CAM and is considering further initiatives in the light of the Department of Health proposals. The Medical Research Council has publicly stated that it welcomes quality applications in this area: our initial asthma and homeopathy study was alpha rated, the Alexander Technique study was alphaalpha rated and funded. There is clearly now an opportunity for substantial growth in this area of research and the track record that we have developed in Southampton makes us well placed to capitalize on these initiatives.

Over the last 8 years we have created a unique multidisciplinary team (non-clinical post-docs, doctors, nurses, physiotherapists, pharmacists and health psychologists) in Southampton, which has developed considerable skill in primary clinical research within CAM. These studies have been directed at asking not only where complementary therapies may be most applicable but also whether and how they work. Furthermore, our research has led us to understand that the nature and content of the therapeutic relationship within complementary medicine is of paramount importance, and therefore we are in the process of developing clinical trial methodology that will allow us to look at the consultation independently from a particular therapeutic intervention, focusing particularly on the non-specific effects of homeopathy and acupuncture in chronic disease. The major studies in which our unit has been involved to date are as follows:

- Unconventional allergy testing (paper published; George Lewith/Jackie Broomfield).

- IIPCOS-II. A study to evaluate the clinical effects and adverse reactions to homeopathy prescribed in general practice for upper respiratory tract and ear infections. This study was a multicentered, international study; our unit was responsible for three centers within the United Kingdom (study completed and data in the process of being analyzed; Sarah Brien/George Lewith).

- Asthma and homeopathy (paper published; George Lewith/Alan Watkins/Jackie Broomfield/Gina Dolan).

- Acupuncture for chronic mechanical neck pain (study completed, five papers published and two in press; Peter White). 
- Acupuncture for stroke (study completed, two papers published and three in preparation; Val Hopwood).

- Enzyme potentiated desensitization for seasonal rhinitis-in conjunction with Michael Radcliffe (study completed, one paper published and one in preparation; George Lewith).

- Homeopathic proving: this study looks at some of the basic assumptions within the whole development of homeopathy (pilot study published, definitive study published with three additional publications in press or published; Sarah Brien).

- Gene expression in chronic fatigue syndrome in conjunction with Rob Powell and Wendy Barclay, University of Reading (pilot study completed and published; George Lewith).

- Does the patient's perception of the impact of Chronic Fatigue Syndrome (CFS) affect outcome? (study completed and paper in submission with Michael Hyland; George Lewith).

- The Alexander Technique in low back pain (led by Paul Little) (study in progress; George Lewith).

- The placebo effects of acupuncture (pilot study completed and paper in press; Peter White/George Lewith).

- Acupuncture in disabling breathlessness (pilot completed and published, definitive study completed and paper published; Clare Hill/George Lewith).

- The development of a validated questionnaire, which evaluates attitudes to CAM and health beliefs, important potential covariates in evaluating outcome in clinical trials-in conjunction with Michael Hyland) (George Lewith).

- The development of theoretical models (in conjunction with Michael Hyland) based on complexity theory that may underpin the basic mechanisms that underlie the clinical effects of CAM (paper published and further submission in progress; George Lewith).

- Absent healing (study in progress in conjunction with the University of Freiburg, Germany and the University of Reykjavik, Iceland; George Lewith).

- Why patients (re)turn to complementary medicine (a series of ethnographic and questionnaire based studies (5) in progress; Lucy Yardley/Felicity Bishop/George Lewith).

- A study of the effects of a daily supplement of Siberian ginseng extract on well-being of young women with persistent fatigue of $<6$ months' duration-in cooperation with Ann Walker (study in progress; George Lewith).

- A randomized controlled trial of Biobran for chronic fatigue patients (funded by Daiwa, study in progress; George Lewith/Selwyn Richards/Clare McDermott).

- An investigation of the 'Candida syndrome' using an explanatory Randomised Controlled Trial (RCT) in conjunction with laboratory investigations (protocol in submission with Michael Radcliffe) (George Lewith).

- Bromelain, a herbal remedy for the treatment of osteoarthritis. A placebo controlled, randomized trial (study completed, publication and review paper in submission; Sarah Brien).

- The specific and non-specific effects of acupuncture in chronic pain: a combined RCT and qualitative study (Clare Hill and Peter White, Department of Health Fellowship).

- The placebo/Streitberger needle. A series of clinical trials and imaging experiments (PET) to evaluate its validity and the underlying mechanism of acupuncture (Peter White in conjunction with the Wellcome Imaging Unit, University College, London).

- Research into the role of CAM in the care of patients with cancer (successful submission to the Department of Health, study in progress with Jessica Corner) (George Lewith).

- Applied kinesiology; is it an effective treatment for back pain? (study in progress; Sue Hall).

- Homeopathic remedies as a treatment for rheumatoid arthritis: is it the medication or the homeopathic process that benefits patients? (protocol completed, initial funding obtained, one publication published; Sarah Brien/ Laurie Lachance).

- The development of a practitioner scale to evaluate consultation content (in development; Sarah Brien/Laurie Lachance).

- A qualitative study of the effects of acupuncture in chronic pelvic pain (in development; Will Stones, Clare Hill and Peter White).

- Devil's Claw and osteoarthritis of the knee. A Phase II RCT (protocol completed and funding obtained, data collection July 2004, one publication in submission; Sarah Brien).

- A Cochrane systematic review of micronutrient supplementation for glycemic control in type II diabetes (in progress; Damian Smith).

- Predictors of CAM use in asthma. Proposal in submission to Wellcome (Primary Investigator; George Lewith).

- An investigation into how local ethics committees manage CAM submissions (in submission, The Nuffield Foundation; Gay Walker, George Lewith, Jane Maher).

- The patient perceived value of a Traditional Chinese diagnosis in chronic pelvic pain (Clare Hill/George Lewith).

- Endometriosis. We would like to look at how endometriosis is treated by CAM practitioners, evaluate how patients perceive CAM in the context of their endometriosis treatment and based on these more general investigations, develop clinical trial methodology to evaluate the use of Chinese herbal medicines and acupuncture as treatments, in both short-term and long-term, for endometriosis (Andrew Flower/George Lewith).

- Experimental test of generalized entanglement as predicted by weak quantum theory. NEST-2003-1 Adventure submission (in collaboration with Harald Walach, Freiburg; George Lewith).

- Whole systems research methods for the evaluation of CAM; learning from shared experience. European 
Scientific Foundation (ESF) submission (in collaboration with Kate Thomas, Sheffield and Vinjar Fonnebo, Tromso; George Lewith).

- The use of intuition in clinical decision making in CAM (one paper in press, one paper in submission; Sarah Brien).

- Emotional and spiritual communication in the CAM consultation. A qualitative enquiry (protocol developed, funding being sought, paper in submission; Sarah Brien).

- Practitioners' perceptions of effective consultations. Protocol in development. Sarah Brien in conjunction with Department of Health, PhD student.

- Developing research strategies for the future of homeopathy. Publication in submission (in conjunction with Faculty of Homeopathy, Royal London Homeopathic Hospital (RLLH) and University of Liverpool; Sarah Brien/George Lewith).

- A comparison of sensitivity to change of several outcome measures following treatment in a complementary medicine clinic (George Lewith/Michael Hyland).

- The superficial circulation in the skin: a comparison of acupuncture and non-acupuncture points. What does this tell us about the mechanism of needling? (Val Hopwood/ Geraldine Clough/George Lewith/Martin Church).

- A randomized controlled trial of acupuncture for the treatment of hyperventilation syndrome (in submission, Physiotherapy Research Foundation; Denise Gibson/ Anne Bruton/George Lewith).

- Complementary treatments for recurrent lower urinary tract infection in Primary Care (MRC submission; in collaboration with Paul Little).

- Nystatin and diet in polysymptomatic patients (in collaboration with Michael Radcliffe).

- Blood ergosterol as a measurement of Candida syndrome: a pilot project (in collaboration with Michael Radcliffe and others).

Each of these major studies is of substantial size and some plan to recruit 500 or more individuals. We have also been involved in a number of minor projects and have built close links with Professor Paul Little in Primary Care, Professor Lucy Yardley in Health Psychology, Professor Philip Prescott in Mathematics, Professor Jessica Corner in the School of Nursing and Debbie Layton in the Drug Safety Research Unit. Our external links include research cooperation with Ann Walker in the Department of Nutritional Medicine at the University of Reading, Ted Kaptchuk in the Complementary Medical Research Unit at Harvard, Michael Hyland in the Department of Health Psychology at the University of Plymouth, Peter Fisher and Robbert van Haselen at the Royal London Homeopathic Hospital, Janet Richardson at the University of Westminster where Dr Lewith holds a Visiting Professorship, Laurie Lachance, a visiting scholar from the University of Michigan, Ann Arbor, MI and Aslak Steinsbekk, supported by the Norwegian Medical Research Council. We have also been involved in cooperative publications with the Department of Complementary Medicine at the University of Exeter and Brian Berman's Complementary Medical Research Unit in Baltimore, MD.

\section{Teaching}

We run a Special Study Unit on CAM familiarization for the third year medical students, chiropractic students and student nurses to give them a brief introduction to complementary and alternative therapies. This course includes placements with CAM practitioners. Lectures on acupuncture and pain are given for the School of Medicine Foundation Course and Term 4 teaching, and the fourth year projects on CAM supervised.

We also run an annual research strategy conference in conjunction with the Research Council for Complementary Medicine and regular critical appraisal courses for CAM practitioners.

\section{Cooperation with Professional Organizations}

The government is anxious to ensure that the provision of complementary medicine is evidence-based and safe. We have cooperated with a number of professional organizations in order to try and achieve this. These include the Society of Teachers of the Alexander Technique, the Acupuncture Association of Chartered Physiotherapists, the British Acupuncture Council, the Acupuncture Research Centre, the National Institute of Medical Herbalists and the Anglo-European College of Chiropractic. These initiatives have involved both regulation and specific research projects. Furthermore, George Lewith and Stephen Holgate have been involved in establishing a Royal College of Physicians sub-committee on complementary medicine. Our unit has played an active part in the House of Lords' Select Committee Report on Complementary Medicine (2000) and three pages of this report are dedicated to the activities within Southampton. Southampton Medical School has also played an important role in the development of the Foundation for Integrated Health, particularly with respect to its research and development agenda. George Lewith is President Elect of the International Society for CAM Research and through that we are initiating a number of projects that include whole systems research workshops and regular annual international conferences. He is also a Director of the Marylebone Trust and Member of DH National Capacity Building Award Committee.

\section{Research Supervision}

George Lewith, Sarah Brien and Peter White supervise PhD students, Fourth Year Students and MSc Students from various departments within the University. Current and recent supervision are as follows:

1. Val Hopwood, PhD (GL). A multicentre study evaluating the effects of acupuncture in stroke (completed 2003). 
2. Peter White, $\mathrm{PhD}$ (GL). A multicentre study evaluating the effects of acupuncture in chronic mechanical neck pain (completed 2002).

3. Karen Sharples, MSc Psychology (GL co-supervisor). Developing a protocol to contextualize the therapeutic consultation (completed 2001).

4. Felicity Bishop, Economic and Social Research Council (ESRC) Studentship. Why people (re)turn to CAM (GL co-supervisor with Dr Lucy Yardley).

5. Sue Hall, PhD (GL and SB). Applied kinesiology for low back pain: a randomized clinical trial with an initial feasibility study.

6. Clare Hill, PhD (GL and PW). Non-specific effects of acupuncture (Department of Health Fellowship).

7. John Shao, MSc Rehabilitation (GL co-supervisor with Dr Alan Borthwick). The attitudes of acupuncturists to traditional acupuncture (2002).

8. Damian Smith, MSc Health Services Research (GL). A systematic review of glycemic control with micronutrients in Type II diabetes.

9. Anthony Godfrey, (GL) Fourth year student project. The effects of lavender oil on mild insomnia (completed 2004).

10. Helen Fagbemi, (PW) Fourth year student project. A qualitative investigation into the patient perceived effect of acupuncture (completed 2004).

11. Andrew Flower, PhD (GL co-supervisor with Dr Paul Little). The use of Chinese herbal medicines as a treatment for endometriosis (project awaiting approval).

12. Fiona Barlow, PhD (GL co-supervisor with Dr Jan Walker). The effects of Reiki on patients with cancer. A mixed methods evaluation (project awaiting approval).

13. Jackie Harewood, $\mathrm{PhD}$ (GL co-supervisor). Why do patients with cancer seek CAM: a two-phased qualitative and quantitative study.

14. Ron Feise, $\mathrm{PhD}$ (in conjunction with Maureen Simmonds, School of Health Professions). Formal and comprehensive comparison of disease-specific selfreport measures and physical performance tests for low back pain.

15. Caroline Eyles, $\mathrm{PhD}$ (GL and SB). A qualitative evaluation of the therapeutic relationship within homeopathy. Department of Health Fellowship.

16. Aslak Steinsbekk. The evaluation of homeopathy in the treatment of childhood upper respiratory tract infections (co-supervision with the University of Tromso and Visiting Research Fellow at the University of Southampton.

\section{Grants Obtained To Date}

1. The establishment of this unit in 1995 was generously supported by a 3 year grant from the Maurice Laing Foundation in order to pay university overheads, secretarial support and sessional salaries (£120 000). Further grants have been awarded from the Maurice Laing
Foundation for administrative expenses, nursing and statistical help until May 2006 ( $£ 603$ 073).

2. Smith's Charity $£ 100000$ for homoeopathy and asthma study.

3. Boiron Ltd $£ 20000$ for homoeopathy and asthma study.

4. South \& West Region $£ 38000$ for homoeopathy and asthma study.

5. South \& West Region $£ 173000$ for acupuncture and stroke study.

6. Dorset Area HA $£ 45000$ p.a. for complementary therapy outreach clinics and outcome audit.

7. Wiltshire Area HA $£ 100000$ lump sum for complementary therapy outreach clinics and outcome audit.

8. South \& West Region $£ 1000$ Delphi Project report on complementary medicine.

9. International Society of Professional Aromatherapists $£ 1800$ for equipment purchased for aromatherapy study.

10. Quest $£ 4000$ for equipment purchased for aromatherapy study.

11. Brain Immune Network Group (BING) $£ 3000$ funds raised for the Brain Immune Network Group inaugural meeting November 1995 held at the Institute of Neurology, London.

12. Unilever $£ 5500$ to investigate the autonomic effects of tea.

13. Maurice Laing Foundation $£ 7500$ salary support for Alan Watkins.

14. Smith's Charity $£ 2000$ to support Brain Immune Network Group.

15. BMA Joan Dawkins Prize $£ 10000$ to support third year undergraduate course.

16. Homoeopathic Research Foundation $£ 3000$ to support third year undergraduate course.

17. Smith's Charity $£ 109000$ to support acupuncture and chronic neck pain study.

18. Hospital Savings Association (HSA), Wessex MT and others $£ 3500$ to support $\mathrm{PhD}$ expenses for Peter White.

19. Persistent Virus Disease Research $£ 10000$ to support chronic fatigue syndrome study.

20. Vega Grieshaber $£ 3000$ to support Vegatest study.

21. Asthma, Allergy and Inflammation Research (AAIR) $£ 1000$ to support Vegatest study.

22. The AIM Foundation; (AIM) $£ 2000$ to support Vegatest study.

23. Wellcome Trust $£ 56600$ to support proving study.

24. South East Region $£ 39655$ to support EPD study.

25. GUS Charity $£ 50000$ to support EPD study.

26. University of Southampton $£ 3200$ p.a. to support third year undergraduate course.

27. European Union (EU) 5th frame $£ 8565$ to support European Healing Study (Total funding of project $£ 1489000)$.

28. MRC $£ 585956$ in cooperation with the Department of Primary Care to fund a clinical trial on the Alexander Technique. 
29. Elizabeth, Lady Cowdray's Charity Trust $£ 5000$ to support placebo study.

30. Boots the Chemist $£ 5000$ p.a. to support ESRC studentship.

31. Garfield Weston Foundation $£ 25000$ to support breathlessness study.

32. Dr Susil Kumar \& Jamila Mitra Charitable Trust $£ 10000$ to support breathlessness study.

33. The Hospital Saving Association Ltd $£ 60000$ to support Sarah Brien.

34. The Rainford Trust $£ 1000$ to support research fellows.

35. Daiwa Pharmaceutical Co. Ltd $£ 49000$ to support Biobran and chronic fatigue syndrome study.

36. Southampton Comp Med Research Trust $£ 20000$ to support Bromelain study.

37. Department of Health $£ 98936$ to support cancer study (Primary investigator: Professor Jessica Corner).

38. Department of Health $£ 181496$ to support Dr Peter White (Fellowship); to investigate the effects and mechanisms of acupuncture in chronic pain. Paired with PhD Fellowship (Clare Hill).

39. Department of Health $£ 152823$ to support Clare Hill ( $\mathrm{PhD}$ Fellowship); to investigate the non-specific effects of acupuncture.

40. Samueli Institute USA $\$ 70000$ to support homeopathy and RA study (R\&D Poole General Hospital-funding research nurse 1 day per week).

41. Royal College of General Practitioners (RCGP) £1965 to support Dr Damian Smith (A systematic review of micronutrients for glycemic control in Type II Diabetes.

42. Southampton Comp Med Research Trust £201 464 to support Devil's Claw study.

43. Pascoe Pharmazeutische Praeparate GmbH $£ 58857$ to support GCP for Devil's Claw study.

44. Department of Health $£ 207149$ to support Dr Sarah Brien (Fellowship) to investigate the therapeutic relationship in CAM. Paired with $\mathrm{PhD}$ Fellowship (Caroline Eyles).

45. Department of Health $£ 162509 \mathrm{PhD}$ Fellowship for Caroline Eyles to investigate the homeopathic practitioners' perceptions of what makes an effective consultation.

46. Southampton Comp $£ 3000$ Does a sense of coherence measure Med Res Trust outcome to CAM treatment?

46. Physiotherapy Research $£ 15000$ RCT of acupuncture for the treatment Foundation of hyperventilation syndrome (Denise Gibson/Anne Bruton/George Lewith).

47. Acupuncture Association of Chartered Physiotherapists (AACP) $£ 5124$ Superficial circulation of the skin: a comparison of acupuncture and non-acupuncture points.

48. Garfield Weston $£ 10000$ to support Department of Health Foundation acupuncture studies.

49. Primary Medical Care (PMC) Reserve $£ 10000$ Herbal medicine project.
50. Allergy UK (co-applicant) $£ 3500$ Blood ergosterol as a measurement of Candida syndrome (Michael Radcliffe).

The Southampton Complementary Medical Research Trust was specifically established to raise money and aid the research development at the Complementary Medicine Research Unit at the University of Southampton. It is a charity registered in the United Kingdom (no. 1094802).

\section{Personnel}

(All still with the department unless otherwise indicated)

Dr George Lewith, Honorary Senior Research Fellow, Department of Medicine, 1995-98; Senior Research Fellow 1998-2005; Reader 2005- and Honorary Consultant Physician, Southampton General Hospital, 1998-

Miss Felicity Bishop, ESRC Studentship, 2001-

Mrs Trish Boyle, Part-time Research Nurse, 2002-

Mrs Vicky Brickley, Part-time Research Assistant, 1999-99

Dr Sarah Brien, HSA Post-doctoral Fellowship, IIPCOS-2 study, Proving study, 1998-2002, rheumatoid arthritis and osteoarthritis studies 2002-04; Senior Research Fellow, The therapeutic relationship in Complementary and Alternative Medicine, Department of Health funded 2004-08

Ms Jackie Broomfield, Research Nurse, 1996-2001

Mrs Jackie Burnham, Secretary, 1995-

Mrs Elain Chivers, Part-time Research Assistant, 2000-01

Mrs Jane Cousins, Part-time Secretary, 2004-

Miss Gina Dolan, Research Assistant, 1996-98

Mrs Caroline Eyles, PhD student, Homeopathic practitioners' perceptions of what makes an effective consultation, 2004-

Mr Andrew Flower, PhD Student, Chinese herbal medicine and endometriosis, 2004-

Mrs Sue Hall, Research Fellow, 2001-

Miss Clare Hill, Research Nurse, Acupuncture and breathlessness study, 2002-03; Research Fellow, 2003-

Mrs Val Hopwood, PhD Student, Acupuncture and stroke study, 1997-03; Research Fellow, 2004-

Miss Vicky Irwin, Research Acupuncturist, 2004

Ms Christine Little, Systematic Reviews, 1998-2001

Dr Laurie Lachance, Visiting Scholar (Ann Arbor, Michigan). Developing randomized controlled trials to evaluate the use of homeopathy in rheumatoid arthritis, 2001-2002

Dr J Lorraine Low, Part-time Statistician, 1998-99

Miss Clare McDermott, Research Assistant, 2004-

Dr John McDonald, Part-time Statistician, 1999-2000

Dr David Owen, Member of the Faculty of Homoeopathy, Teaching Module, 1996-

Professor Philip Prescott, Part-time Statistician, 1999-

Mrs Karen Prout, Part-time Clerical Assistant, 1996-97

Dr Damian Smith, Research GP Registrar, 2003-

Mrs Anne Smithson, Part-time Clerical Assistant, 2000-03

Mr Aslak Steinsbekk, Visiting Research Fellow and $\mathrm{PhD}$ student, 2003-04

Dr Alan Watkins, Locum Lecturer, Department of Medicine, 1995-98 
Miss Hannah Watson, Part-time Research Assistant, 1999-2000

Mrs Fran Webley, Research Nurse, 2000-01

Mrs Chris Wheeler, Part-time Clerical Assistant, 1998-99

Mrs Julie White, Part-time Research Assistant, 1997-99

Dr Peter White, PhD student, 1998-2002; Research Fellow, 2002-03; Senior Research Fellow, Department of Health funded, 2003-

Dr Jinpan Zou. British Council Scholarship. Developing techniques to look at immunological markers which will elucidate the effect of acupuncture in asthma, and the development of an RCT protocol for evaluating acupuncture in asthma, 2002

\section{Publications 2001-04}

1. Harmsworth K, Lewith GT. Attitudes to traditional Chinese medicine amongst Western trained doctors in the People's Republic of China. Soc Sci Med 2001;52:149-53.

2. MacPherson H, Lewith GT. Reporting adverse events following acupuncture. Physiotherapy 2001; 87:21-4.

3. Lewith GT, Kenyon JN, Holgate ST, Broomfield J, Prescott P, Goddard J. Does electrodermal testing correlate with skin prick tests for allergies: a doubleblind, randomised, controlled trial. $\mathrm{Br}$ Med J 2001;322:131-4.

4. Owen D, Lewith G, Stephens CR. Can doctors respond to patients' increasing interest in complementary and alternative medicine? Br Med J 2001;322:1547.

5. Lewith GT. Editorial. Complementary medicine: a suitable case for integration. Update 2001;71.

6. Owen D, Lewith GT. Complementary and alternative medicine (CAM) in the undergraduate medical curriculum: the Southampton experience. Med Educ 2001;35:73-7.

7. Yardley L, Sharples K, Beech S, Lewith G. Developing a dynamic model of treatment perceptions. J Health Psychol 2001;6:269-82.

8. Brien S, Lewith GT. Why are you doctors? The importance of care and compassion. A Report of the Integrated Medicine Conference on 23/24 January 2001. Clin Med 2001;1: 223-6.

9. Walach H, Lewith G, Bosch H, Utts J. Letter to the editor. Pain 2001;91:79-89.

10. Lewith GT, Hyland M, Gray SF. Attitudes to and use of complementary medicine among physicians in the United Kingdom. Complement Ther Med 2001;9: 167-72.

11. Christie S, Walker AF, Lewith GT. Flavonoids-a new direction for the treatment of fluid retention? Phytothe Res 2001;15:467-75.

12. Davis CL, Lewith GT, Broomfield J, Prescott P. A pilot project to evaluate the effects of acupuncture versus two control interventions in the treatment of disabling breathlessness. J Altern Complement Med 2001;7:633-9.

13. Hopwood V, White $\mathbf{P}$. Poor reviews may not give a true reflection of the evidence. Physiotherapy 2001;87:549-51.

14. Park J, Hopwood V, White AR, Ernst E. Effectiveness of acupuncture for stroke: a systematic review. J Neurol 2001;248:558-63.

15. White A, Cummings M, Hopwood V, MacPherson H. Informed consent for acupuncture-an information leaflet developed by consensus. Acupunct Med 2001; 19:123-9.

16. Brien SB. It is difficult to research homoeopathic remedy provings. Commentary. Forsch Komplementarmed Klass Naturheilkd 2001;8:312-4.

17. Lewith GT, Watkins AD, Hyland M, Shaw S, Broomfield J, Dolan G, Holgate ST. A double-blind, randomised, controlled clinical trial of ultramolecular potencies of house dust mite in asthmatic patients. $\mathrm{Br}$ Med J 2002;324:520-3.

18. Walach H, Lewith G, Bosch H, Utts J. Spiritual healing as a therapy for chronic pain: a randomized clinical trial. Letter to the editor. Pain 2002;96: 403-12.

19. Birch S, Hammerschlag R, Lewith G. International workshop on acupuncture research methodology: introduction to consensus reports on workshop topics. Clin Acupunct Oriental Med 2002;3:10-11.

20. Sherman K, Lao L, MacPherson H, Lewith G, Hopwood V, Kawakita K. Matching acupuncture clinical study designs to research questions. Clin Acupunct Oriental Med 2002;3:12-5.

21. Owen D. Learning experiences-what works for postgraduates. Homeopathy 2002;91:95-8.

22. Walach H, Jonas WB, Lewith GT. The role of outcomes research in evaluating complementary and alternative medicine. Altern Ther Health Med 2002;8:88-95.

23. Lewith GT, Hyland M, Holgate S. Authors' reply. Letter. Br Med J 2002;325:42-3.

24. Walach H, Bosch H, Haraldsson E, Marx A, Tomasson $\mathrm{H}$, Wiesendanger $\mathrm{H}$, et al. Efficacy of distant healinga proposal for a four-armed randomized study (EUHEALS). Forschende Komplementarmedizin 2002;9:168-76.

25. Lewith GT, Hyland ME. Oscillatory effects in a homeopathic clinical trial: an explanation using complexity theory, and implications for clinical practice. Br Homeopath J 2002;91:145-9.

26. Lewith GT, Hyland M, Shaw S. Do attitudes toward and beliefs about complementary medicine affect treatment outcomes? Am J Public Health 2002;92: 1604-6.

27. Lewith GT, Chan J. An exploratory qualitative study to investigate how patients evaluate complementary 
and conventional medicine. Complement Ther Med 2002;10:69-77.

28. Lewith GT, Broomfield J, Prescott P. Complementary cancer care in Southampton: a survey of staff and patients. Complement Ther Med 2002;10:100-6.

29. White P, Lewith GT, Berman B, Birch S. Reviews of acupuncture for chronic neck pain: pitfalls in conducting systematic reviews. Rheumatology 2002;41: 1224-31.

30. Lewith GT. What complementary or alternative therapy is available for RA. NeLH Musculoskelet Dis VBL 2002.

31. Lewith GT. Commentary on the effect of acupuncture on nausea of pregnancy: a randomized, controlled trial by Knight et al. Forschende Komplementarmedizin Journal Club 2002;9:177-85.

32. Hopwood V. Chairman's report. AACP J 2003.

33. Lewith GT. Homeopathic arnica. Letter to the editor. JRSM 2003;96:205.

34. Hyland ME, Lewith G, Westoby C. Developing a measure of attitudes: the holistic complementary and alternative medicine questionnaire. Complement Ther Med 2003;11:33-8.

35. Lewith G, White P. Side effects associated with acupuncture and a sham treatment: perhaps we should take a closer look at what is really responsible? Letter to the editor. J Altern Complement Med 2003;9:16-9.

36. White P. Attitude and outcome-is there a link in complementary medicine? Letter. Am J Public Health 2003;93:1038.

37. Lewith GT, Breen A, Filshie J, Fisher P, McIntyre M, Mathie RT, Peters D. Complementary Medicine: Evidence base, competence to practice and regulation. Clin Med 2003;3:235-40.

38. White P. Commentary on acupuncture and bronchial asthma: a long term randomized study of the effects of real versus sham acupuncture compared to controls in patients with bronchial asthma by Medici TC, Grebski E, Wug J, Hinz G, Wuthrich B. Forschende Komplementarmed 2003;10:158-9.

39. Radcliffe MJ, Lewith GT, Turner RG, Prescott P, Church MK, Holgate ST. Enzyme-potentiated desensitisation in the treatment of seasonal allergic rhinitis; a double blind randomised controlled study. $\mathrm{Br}$ Med $\mathrm{J}$ 2003;327:251-4.

40. Lewith GT. Can we evaluate electrodermal testing? Complement Ther Med 2003;11:115-7.

41. Powell R, Ren J, Lewith G, Barclay W, Holgate S, Almond J. Identification of novel expressed sequences, up-regulated in the leukocytes of Chronic Fatigue Syndrome patients. Clin Exp Allergy 2003;33: 1450-6.

42. Lewith GT. National Electronic Library for Health website. Complement Med www.nelh.nhs.uk/ musculoskeletal.
43. Lewith GT. Evaluating traditionally based systems of medicine with particular reference to acupuncture. Clin Acupunct Oriental Med 2003;4:78-83.

44. Brien S, Lewith G, Bryant T. Ultramolecular homoeopathy has no observable clinical effects. A randomized, double-blind, placebo-controlled proving trial of Belladonna 3C0. Br J Clin Pharmacol 2003;56: 562-8.

45. Lewith GT. A Conference on developing research strategies in CAM. Complement Ther Med 2003;11: 191-2.

46. White P, Lewith G, Hopwood V, Prescott P. The placebo needle, is it a valid and convincing placebo for use in acupuncture trials? A randomised, single blind, cross-over trial. Pain 2003;106:401-9.

47. Brien SB, Lewith $\mathbf{T}$. Letter on inappropriate outcomes and flooring/ceiling effects invalidate study conclusion. Thorax 2003;58:9.

48. Lewith GT. Can practitioners be researchers? Complement Ther Med 2004;12:2-5.

49. Lewith GT, Prescott P, Davis CL. Can a standardised acupuncture technique palliate disabling breathlessness: a single blind, placebo controlled, crossover study. Chest 2004;125:1783-90.

50. Verhoef MJ, Lewith G, Ritenbaugh C, Thomas K, Boon H, Fønnebø V. Whole Systems Research: moving forward. FACT 2004;9:87-90.

51. Lewith GT, Bensoussan A. Joint editors for a Medical Journal of Australia series on complementary medicine with authorship on 3 articles. Complementary and alternative medicine-with a difference. MJA 2004;180:585-6.

52. Owen D, Lewith GT. Teaching integrated care: CAM familiarisation courses. MJA 2004;181:276-8.

53. Bensoussan A, Lewith GT. Complementary medicine research in Australia: a strategy for the future. MJA 2004;181:331-3.

54. Brien SB, Lachance L, Lewith GT. Are the therapeutic effects of homeopathy attributed to the consultation, the homeopathic remedy, or both? A protocol for a future exploratory feasibility trial in patients with rheumatoid arthritis. JACM 2004;10:499-502.

55. Brien S. Attitudes about complementary and alternative medicine did not predict outcome in a homeopathic proving trial. JACM 2004;10:503-5.

56. Brien S, Prescott P, Owen D, Lewith GT. How do homeopaths make decisions? An exploratory study of inter-rater reliability and intuition in the decision making process. Homeopathy 2004;93:125-31.

57. Bishop F, Yardley L, Lewith G. Associations and explanations: who uses complementary medicine and why? Health Psychol Update 2004;13:12-9.

58. Campbell A, Hopwood V. Debate-patients should be encouraged to treat themselves. Acupunct Med 2004;22:141-5.

59. White P, Lewith G, Prescott $\mathbf{P}$. The core outcomes for neck pain-validation of a new outcome measure. Spine 2004;29:1923-30. 
60. Lewith GT, Prescott P, Davis CL. Letter (Author's reply to commentary on acupuncture for disabling breathlessness). FACT 2004;9: 299-300.

61. Steinsbekk A, Bentzen N, Fonnebo V, Lewith G. The use of simplified constitutional indications for self-prescription of homeopathic medicine. Complement Ther Med 2004;12:112-7.

62. Corner J, Harewood J, Maslin-Prothero S, Lewith G, Maher J, Young T, Gwilliam C. The drivers for complementary therapy use in cancer. Abstract. Complement Ther Med 2004;12:171.

63. White P, Lewith G, Prescott P, Conway J. Acupuncture versus placebo for the treatment of chronic mechanical neck pain. A randomised, controlled trial. Ann Intern Med 2004;141:911-20.

64. Lewith G. Developing research strategies: the challenge and the RCT. Complement Ther Med 2004;12:145-54.

65. Brien SB, Lewith G, Walker A, Hicks SM, Middleton D. Bromelain as a treatment for osteoarthritis; a review of clinical studies. Evid Based Complement Med 2004;1:251-7.

66. Steinsbekk A, Bentzen N, Fonnebo V, Lewith G. Randomized controlled trials on treatment by homeopaths and self-treatment with homeopathic medicines: design and protocol. J Alt Comp Med 2004;10: 1027-32.

67. Steinsbekk A, Bentzen N, Fonnebo V, Lewith G. Self treatment with one of three self selected, ultramolecular homeopathic medicines for the prevention of upper respiratory tract infections in children. A double blind randomized placebo controlled trial. $\mathrm{Br} \quad \mathrm{J}$ Clin Pharmacol 2005;59:447-55.

68. Hopwood V, Lewith GT. Does acupuncture help stroke patients become more independent? J Alt Comp Med 2005;11:175-7.

69. Lewith GT, Brien S, Hyland M. Presentiment or entanglement? An alternative explanation for apparent entanglement in provings. Homeopathy 2005; 94:92-5.

70. Brien SB, Lewith G. Assessing homeopathic proving using questionnaire methodology. Consideration and implications for future studies. Forsch Komplementarmed Klass Naturheilkd 2005;12:DOI: 1159/ 000084837.

71. Pariente J, White P, Frackowiak RSJ, Lewith G. Expectancy and belief modulate the neuronal substrates of pain treated by acupuncture. NeuroImage 2005;25:1161-7.

72. Bruton A, Lewith GT. The Buteyko breathing technique for asthma: a review. Complement Ther Med 2005;13:41-6.

73. White PJ, Lewith G. Response to letter. Acupuncture for chronic mechanical neck pain. Ann Intern Med 2005; $142: 874$.

\section{Articles in Press 2005}

74. McGregor G, Fiebich B, Wartenberg A, Brien S, Lewith G, Wegener T. Devil's Claw (Harpagophytum procumbens): an anti-inflammatory herb with therapeutic potential. Phytochem Rev.

75. Bishop FL, Yardley L, Lewith G Developing a measure of treatment beliefs: the complementary and alternative medicine beliefs inventory. Complement Ther Med.

76. Lewith GT. Book Review: Women's health in complementary and integrative medicine: a clinical guide. JACM 2005;11:1.

77. White P, Lewith GT. Response letter. Ann Intern Med.

78. Lewith GT. The development of a multidisciplinary complementary medical research unit in the United Kingdom. Semin Integr Med.

79. Lewith GT, Godfrey AD, Prescott P. A double-blind, randomised, pilot trial evaluating the aroma of Lavendula augustifolia as a treatment for mild insomnia. JACM.

80. Borthwick A, Shao Y, Lewith GT, Hopwood V. Attitudes towards traditional acupuncture (TA) among acupuncture clinicians in the United Kingdom. Evid Based Integr Med.

81. Verhoef M, Lewith GT, Ritenbaugh C, Boon H, Fleishman S, Leis A. Complementary and alternative (CAM) whole systems research (WSR): beyond identification of inadequacies of the RCT. Complement Ther Med.

82. Steinsbekk A, Bentzen N, Fonnebo V, Lewith G. Homeopathic care for the prevention of upper respiratory tract infections in children-a pragmatic randomized controlled trial comparing individualised homeopathy and self-selected conventional care. Complement Ther Med.

\section{Articles Currently in Submission/Preparation}

83. Hyland ME, Sodergren SC, Lewith GT. The role of positivity to illness in chronic fatigue patients. $J$ Health Psychol.

84. Hopwood V, Lewith GT, Prescott P. A single-blind, randomised, placebo controlled study of acupuncture for stroke. Stroke.

85. Hopwood V, Lewith GT, Prescott P. A comparison of the Scandinavian Stroke Scale and the Bartel Index.

86. Radcliffe MJ, Prescott P, Lewith GT, Church MK. Do incremental skin prick and conjunctival provocation tests predict symptom severity in seasonal allergic rhinoconjunctivitis?

87. Brien SB, Lewith G, McGregor G. WartenbergDemand A. Devil's Claw (Harpagophytum procumbens) as a treatment for osteoarthritis: a review of efficacy and safety. Br J Clin Pharm. 
88. Brien SB, Lewith G, Walker A, Boyle T, Bundy R. Bromelain as an adjunctive treatment for patients with osteoarthritis of the knee; a pilot randomised controlled trial. Br J Clin Pharm.

89. Hicks SM, Bernard S, Radford N, Robinson PA, Christie S, Lewith GT, Walker AF. A multi-nutrient intervention study for persistent fatigue: promising results of a pilot study.

90. Steinsbekk A, Brien SB. Why do parents take their children to homeopaths? A qualitative study.

91. Brien SB. Spiritual and emotional communication in CAM.

92. Brien SB. Intuition in CAM.

93. Bishop FL, Yardley L. Development of the Treatment Process Questionnaire. J Psychosomatic Res.

94. Walach H, Falkenberg T, Fonnebø V, Lewith G, Jonas W. Circular instead of hierarchical : methodological principles for the evaluation of complex interventions. JAMA.

95. Gibson DH, Bruton A, Lewith GT. Is the use of acupuncture beneficial in the treatment of hyperventilation syndrome? - A preliminary randomised pilot study.

96. Richards SCM, McDermott C, Lewith G, Thomas P, Montgomery, J. A placebo controlled, double-blinded, randomised controlled trial of a natural killer cell stimulant (BioBran ${ }^{\mathrm{TM}}$ MGN-3) in Chronic Fatigue Syndrome.

97. White P, Lewith GT, Fagbemi H, Walker J. Patients perceptions of acupuncture - a preliminary qualitative study.

98. Lewith GT, White P. Imaging and acupuncture.

99. Lewith GT, White PJ, Kaptchuk T. Developing a research strategy for acupuncture. Arch Intern Med.

100. Lewith GT. Defining the effect of whole systems. Letter to the editor. Br Med J.

101. Bishop FL, Lewith GT. Who uses CAM? A comprehensive review of demographic characteristics and health factors associated with CAM use. JACM.

102. Bishop FL, Lewith GT. A review of the psychological factors involved in CAM use. Soc Sci Med.

103. Walach H, Bosch H, Lewith G, Naumann J, Schwarzer B, Haraldsson E, et al. The efficacy of distant healing: a four-armed randomised trial in chronic fatigue patients.

\section{Books}

104. Integrated Cancer Care-holistic, complementary and creative approaches. Edited by $\mathrm{Dr}$ Jennifer Barraclough. Dr Lewith has contributed a chapter (Homoeopathy). Oxford University Press, Oxford, UK. 2001.

105. Clinical Research in Complementary Therapies. Principles, Problems and Solutions. Edited by George Lewith, Wayne Jonas and Harald Walach. Churchill Livingstone, UK. 2001.

106. Understanding Complementary Medicine. BMA Publications, London (2002).

107. Berman BM, Gournelos E, Lewith GT. Chapter: Complementary and Alternative Medicine. In Rheumatology. Third Edition. Edited by Hochberg, Silman, Smolen, Weinblatt and Weisman. Mosby. London. 2003. 505-516.

108. Lewith GT. Chapter 140: Complementary medicine for Irritable and Inflammatory Bowel. In Clinical Gastroenterology and Hepatology: The modern clinician's guide. Edited by Weinstein, Hawkey and Bosch. Elsevier Mosby. London. 2005.

109. Lewith GT, Specialist author on Acupuncture. The New Doctor. Ed. David Peters (In press-Dorling Kindersley, London, UK).

110. White P. 'Methodological concerns when designing trials for the efficacy of acupuncture for the treatment of pain'. Chapter in 'Complementary and Alternative Approaches to Biomedicine' Ed: Cooper, E. and Yamaguchi N. Kluwer Academic Publishers, New York. 2004.

111. Hopwood V. Acupuncture in Physiotherapy. Butterworth Heinemann, 2004.

112. Bishop F, Lewith GT. Complementary Medicine. In Cambridge Handbook of Psychology Health \& Medicine. (In press).

113. Lewith GT, Guthrie S. 'Alternative Treatments' in Cambridge Handbook of Effective Treatments in Psychiatry. (In press).

114. Lewith GT. Randomised Controlled Trials. Chapter in 'Researching Health', Edited by Professor M Saks and Professor J Allsop. Published by Sage. (In preparation). 


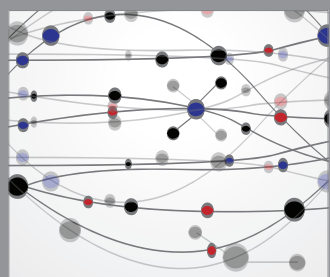

The Scientific World Journal
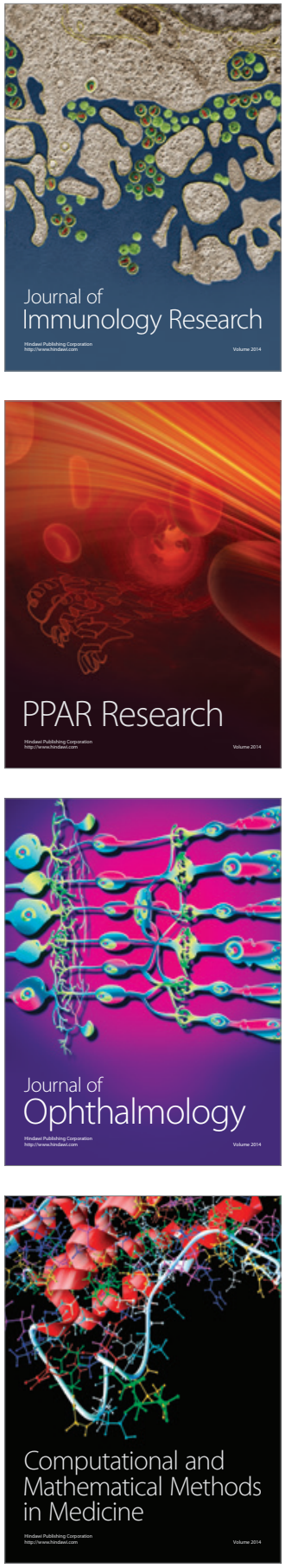

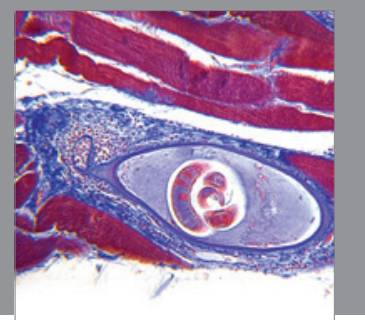

Gastroenterology

Research and Practice
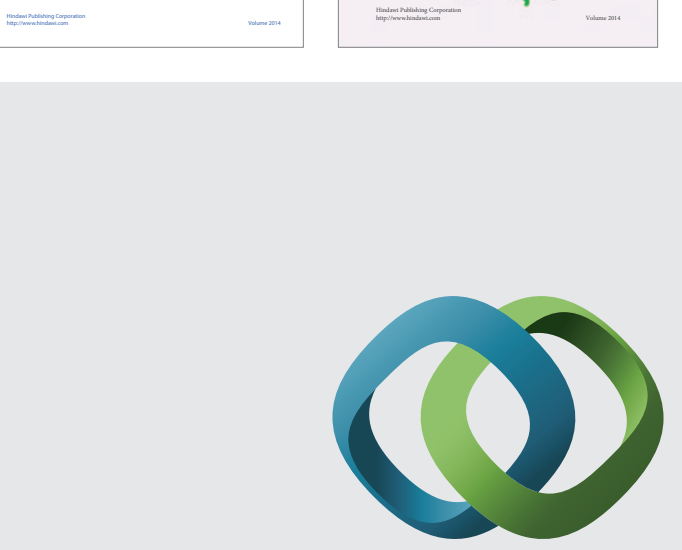

\section{Hindawi}

Submit your manuscripts at

http://www.hindawi.com
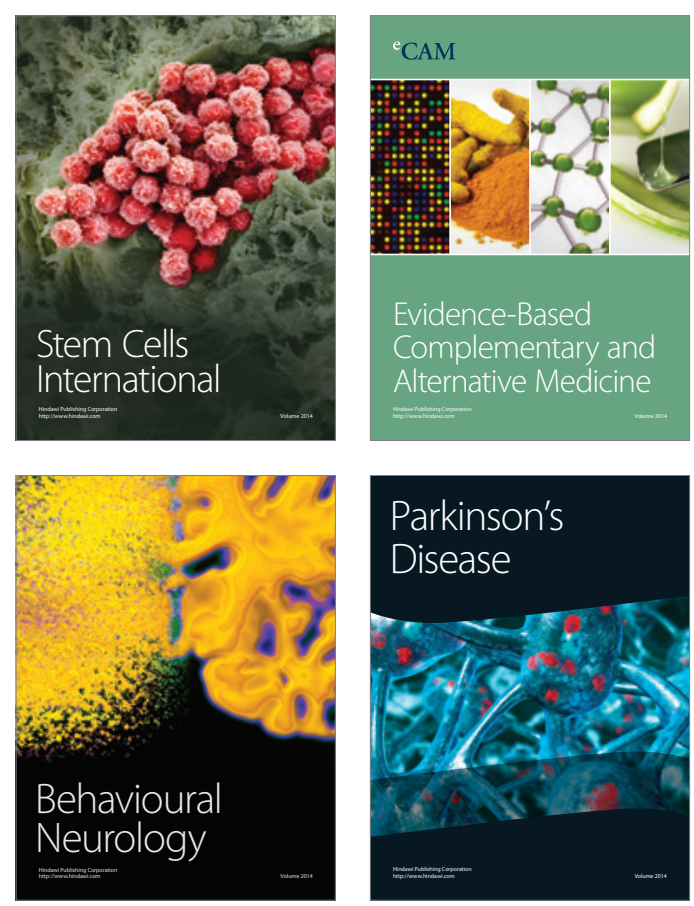

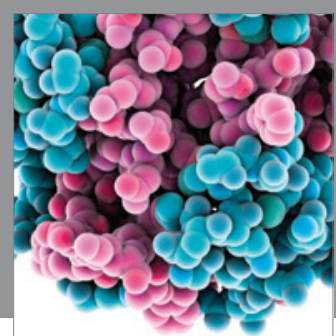

Journal of
Diabetes Research

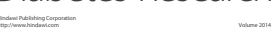

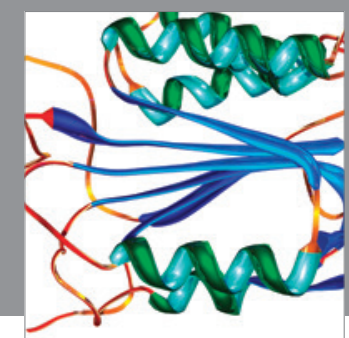

Disease Markers
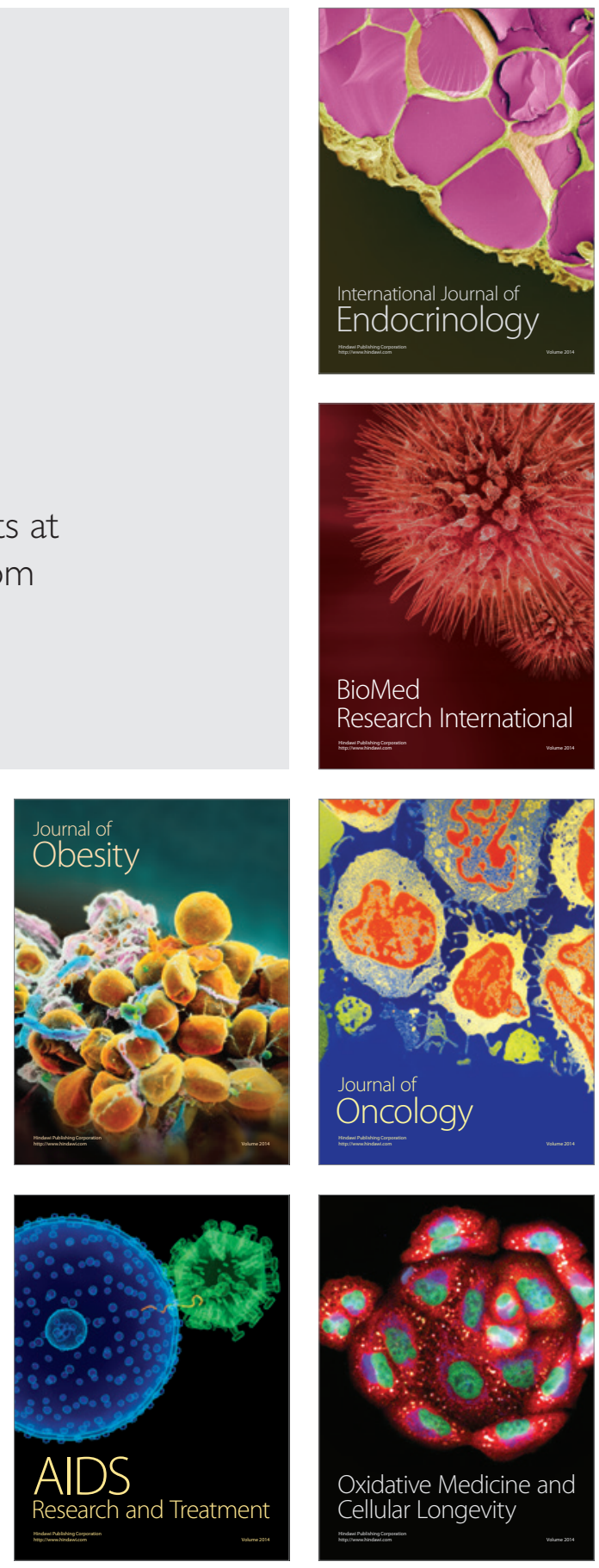